\title{
Entomopathogenic fungi of soils of freshwater swamps, tidal lowlands, peatlands, and highlands of South Sumatra, Indonesia
}

\author{
AYU SAFITRI ${ }^{1}$, SITI HERLINDA ${ }^{2,3, \boldsymbol{v}}$, ARUM SETIAWAN $^{4}$ \\ ${ }^{1}$ Department of Environmental Science, Graduate Program, Universitas Sriwijaya. Palembang 30139, South Sumatra, Indonesia \\ ${ }^{2}$ Department of Plant Pest and Disease, Faculty of Agriculture, Universitas Sriwijaya, Indralaya, Ogan Ilir 30662, South Sumatra, Indonesia. \\ Tel/fax +62-711-580663, •email: sitiherlinda@unsri.ac.id \\ ${ }^{3}$ Research Center for Sub-optimal Lands (PUR-PLSO), Universitas Sriwijaya. Palembang 30139, South Sumatra, Indonesia \\ ${ }^{4}$ Department of Biology, Faculty of Mathematic and Natural Sciences, Universitas Sriwijaya. Indralaya 30662, South Sumatra, Indonesia
}

Manuscript received: 11 June 2018. Revision accepted: 22 November 2018.

\begin{abstract}
Safitri A, Herlinda S, Setiawan A. 2018. Entomopathogenic fungi of soils of freshwater swamps, tidal lowlands, peatlands, and highlands of South Sumatra, Indonesia. Biodiversitas 19: 2365-2373. Ecosystems of lowlands and highlands in South Sumatra have specific characteristics of soils and vegetations that can affect the availability of entomopathogenic fungi. This study aimed to explore and identify species and to determine inoculum potentials of the entomopathogenic fungi from soils of freshwater swamps, tidal lowlands, peatlands, and highlands. Baiting of entomopathogenic fungi on soil samples used the larvae of Tenebrio molitor. The entomopathogenic fungi species found in this research were Beauveria bassiana and Metarhizium anisopliae. The number of the fungal isolates were 30 isolates consisting of nine isolates of $B$. bassiana and 21 isolates of $M$. anisopliae. The highest number of isolates was found in the highland ecosystem (11 isolates) and the lowest was found in peatland ecosystem (4 isolates). The highest percentage average of inoculum potentials of the fungi was found in the high land ecosystem (4.04\%) and the lowest one was found in freshwater swamps ecosystem (2.11\%). Based on the vegetation type, the soil planted with mustard in Talang Patai-Pagaralam (highland ecosystem) had the highest inoculum potentials (9.33\%). These fungi will make an important contribution to the biological control for insect pests in lowland to highland ecosystems in Indonesia.
\end{abstract}

Keywords: Beauveria bassiana, lowlands, Metarhizium anisopliae, peat soils, wetlands

\section{INTRODUCTION}

Many parts of lowlands and highlands of Indonesia are used for agriculture. Lowlands consisting of freshwater swamps, tidal lowlands, and peatlands are the ecosystems having water saturated condition for the whole year (Sudana 2005). The lowland ecosystems for agricultural purposes in Indonesia are distributed in Sumatra, Kalimantan, and Papua Islands covering 11 million ha of tidal lowlands, comprising 9.2 million ha of freshwater swamps, and 14.9 million ha of peatlands, respectively (Mulyani and Sarwani 2013). While the highland ecosystems managed for agriculture with the area of 16.15 million ha are distributed all over Indonesia islands (Center for Agriculture Data and Information System, Secretariat General 2017).

Soils between lowlands and highlands in Indonesia have different characteristics, especially in the moisture, texture, and acidity $(\mathrm{pH})$. The specific characteristics of lowland and highland soils at the four typologies of ecosystems consist of the freshwater swamp, tidal lowlands, peatlands, and highland closely related to specific cultivated vegetations or crops. Paddy usually is cultivated at freshwater swamps (Herlinda et al. 2018; Lakitan et al. 2018a; Lakitan et al. 2018b). There is only a small part of soils in peatlands that can be cultivated with seasonal crops and most peatlands in Indonesia are utilized for forestry and conservation areas (Suriadikarta and Sutriadi 2007). Highlands area usually planted with various types of seasonal and annual crops. Specific vegetation or crop plants could affect the soil microorganisms associated with plant and crop roots (El-Ghany 2015).

Microorganisms such as fungi are found in freshwater swamps and highlands of South Sumatra and can be used to control insect pest called entomopathogenic fungi such as Beauveria bassiana and Metarhizium anisopliae (Herlinda et al. 2008; 2010). The entomopathogenic fungi are proven to be an effective agent to control some insect pests (Chinniah et al. 2016), and they are not harmful toward natural enemies of insect pests (Gholamzadeh-Chitgar et al. 2017). However, there is no complete information for fungi of tidal lowlands and peatlands in that region. B. bassiana and $M$. anisopliae were found to kill insect pests such as Crocidolomia pavonana (Hasyim et al. 2009), Aphis gossypii (Herlinda 2010), Plutella xylostella (Loc and Chi 2007), Lygus spp. (Leland et al. 2005), and Oryctes rhinoceros (Moslim et al. 2009). Entomopathogen, such as entomopathogenic fungi can be explored in soils (El-Ghany 2015). Certain entomopathogen species have adaptation capability in certain soils (Bugeme et al. 2008). Entomopathogen already adapted in freshwater swamp soils or highland soils generally has the specific advantage, i.e., it can adapt more effectively in this soil environment (Erler and Ates 2015). Exploration of entomopathogen starting 
from lowland to highland ecosystems will produce the high variation of species and genetics that can be utilized in the extended area and specific location. The purposes of this study were to explore and identify species and to determine inoculum potentials of the entomopathogenic fungi of soils of freshwater swamps, tidal lowlands, peatlands, and highlands in South Sumatra.

\section{MATERIALS AND METHODS}

\section{Study area}

Soil sampling was carried out in December 2017. The study sites were selected in the agricultural center with specific typology ecosystems in some locations of South Sumatra (Figure 1 and Table 1). The sites consisted of freshwater swamps, tidal lowlands, peatlands, and highlands. Those ecosystems chosen for explorations of entomopathogenic fungi aimed to obtain the fungi adapting in lowland and highland soils. The selected freshwater swamp locations were in Gandus and Musi Subdistricts of Palembang City; Rambutan Subdistrict of Banyuasin District, and Pemulutan Subdistrict of Ogan Ilir District. The selected locations of tidal lowlands were Mulya Sari, Telang Sari, Muara Sungsang Subdistricts of Banyuasin District. The selected peatland locations were in Talang Dabok, Sepucuk, and Kedaton Subdistricts of Ogan Komering Ilir District. The selected highland locations were in Lematang, Tanjung Payang, and Pulau Pinang of Lahat District, and Rimau and Talang Patai of Pagaralam City.
Fungal isolation, purification, and identification were conducted from January to March 2018 in the Laboratory of Entomology, Department of Plant Pest and Disease, College of Agriculture, Sriwijaya University, Indonesia. Supporting data were recorded in terms of soil sampling period, village or city names, coordinate points, and vegetation types or crop plants for each exploration locations (Figure 1 and Table 1). The $\mathrm{pH}$ of soil samples was measured by using a method of Kartika et al. (2018). In this survey, the application of pesticides in the sampling locations was also monitored.

\section{Procedures}

Observation of inoculum potentials of entomopathogenic fungi in the soil

Inoculum potential observation of the entomopathogenic fungi in this research was conducted by exploration of fungi in soils of the freshwater swamps, tidal lowlands, peatlands, and highlands. Entomopathogenic fungi exploration was carried out by modifying the methods of Anwar et al. (2015), i.e., using newly-moultingthird instar of Tenebrio molitor (Yellow mealworm beetle) as insect bait (Tenebrio bait method) which was infested on fungal inoculum of soil samples.

The soil samples were collected from some crop fields in the sampling locations (Table 1). Soils were taken from each location at the diagonal position. Soil samples of 5000 $\mathrm{g}$ were obtained by digging soil at the depth of $5-15 \mathrm{~cm}$ in the vicinity of crop roots, and then they were put into the plastic pouch and labeled with the information of period of the sampling and crop plants.

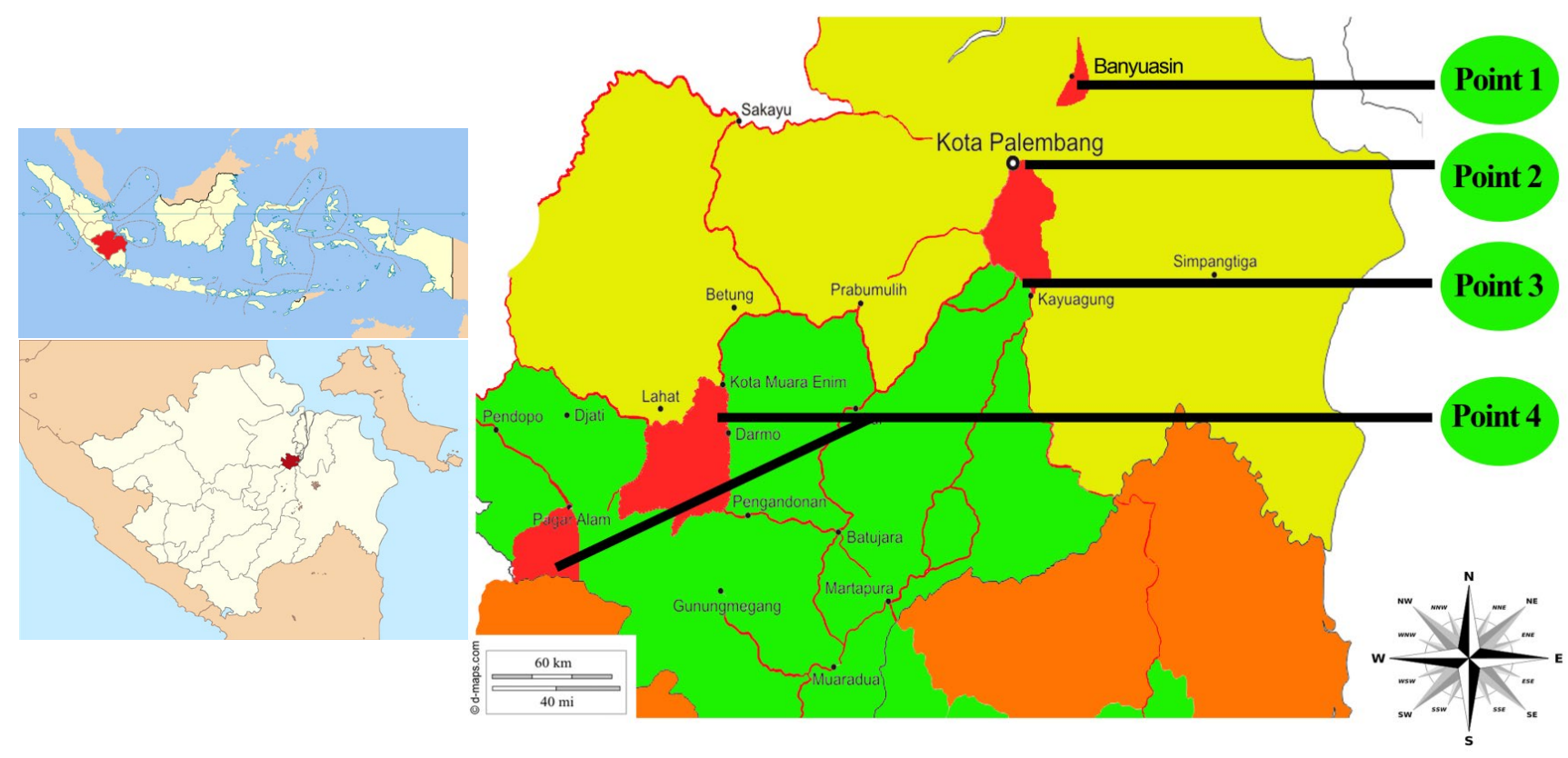

Figure 1. Locations of exploration for entomopathogenic fungi of soils in ecosystems of South Sumatra, Indonesia: point $1=$ tidal lowlands (S $\left.02^{\circ} 40.866^{\prime} \mathrm{E} 104^{\circ} 44.298^{\prime}\right)$, point 2 = freshwater swamps (S 0302.581' E $\left.104^{\circ} 51.231^{\prime}\right)$, point $3=$ peatlands $\left(\mathrm{S} 03^{\circ} 24.840^{\prime} \mathrm{E}\right.$ $\left.104^{\circ} 53.362^{\prime}\right)$, and point $4=$ highlands (S $03^{\circ} 48.063^{\prime} \mathrm{E} 103^{\circ} 32.072^{\prime}$ and S $\left.03^{\circ} 50.174^{\prime} \mathrm{E} 103^{\circ} 31.293^{\prime}\right)$ 
Table 1. Locations of exploration for entomopathogenic fungi in South Sumatra, Indonesia

\begin{tabular}{lllc}
\hline Ecosystems & Village or city & Vegetation or crop plants & Height from sea level (m) \\
\hline Freshwater & Rambutan, Banyuasin & Paddy & 15 \\
swamps & Gandus, Palembang & Paddy & 12 \\
& Musi Dua, Palembang & Paddy & 16.67 \\
\multirow{4}{*}{ Tidal lowlands } & Pemulutan, Ogan Ilir & Paddy & 22 \\
& Mulya Sari, Banyuasin & Corn, paddy, watermelon & 16.33 \\
& Telang Sari, Banyuasin & Corn, coconut, corn + coconut & 18.33 \\
Peatlands & Muara Sungsang, Banyuasin & Coconut, banana, pineapple & 15 \\
& Talang Dabok, Ogan Komering Ilir & Palm, rubber, pineapple & 24 \\
& Sepucuk, Ogan Komering Ilir & Oil palm, rubber, pineapple & 23 \\
Highlands & Kedaton, Ogan Komering Ilir & Oil palm & 19.67 \\
& Talang Patai, Pagaralam & Cabbage & 170 \\
& Pulau Pinang, Lahat & Rubber + coffee & 161 \\
& Tanjung Payang, Lahat & Rubber & 121 \\
& Lematang, Lahat & Paddy & 121.3 \\
\hline
\end{tabular}

Previously, soil samples were sieved by using 5-mesh siever to separate them from crop roots. Then, samples were put into plastic tray (size of $32 \mathrm{~cm} \mathrm{x} 25 \mathrm{~cm} \times 5 \mathrm{~cm}$ ) and yielded $1000 \mathrm{~g}$ of finer soil sample. The finer soil samples were subsequently moisted with sterile aquadest until they obtained the soil moisture of $80-90 \%$ using the method of Chen et al. (2014). The number of larvae used per sampling location was 150 larvae (5 plastic trays each containing 30 larvae) (Table 1), so the total larvae per ecosystem type was as follows: in the freshwater swamps it was 1,800 (150 larvae x 12 sampling locations), in tidal lowlands it was 1,350 (150 larvae x 9 sampling locations), in peatlands it was 1,350 (150 larvae $x 9$ sampling locations), and in highlands it was 2,250 (150 larvae x 15 sampling locations).

The larvae were sterilized with $70 \%$ alcohol, and put on soil-sample surface in a plastic tray. The body of larvae was sprinkled using soil sample of about $5 \mathrm{~mm}$ thick. Subsequently, the plastic trays containing soil samples were covered with black cloth and sprayed with sterile aquadest to maintain humidity of soil samples. The larvae were incubated within soil sample for seven days to provide enough time for entomopathogenic fungi to infect them. Then, the dead larvae infected by the entomopathogenic fungi were recorded daily to determine inolum potential. The inoculum potentials of entomopathogenic fungi in this research were measured according to the percentage of infected Tenebrio bait or hosts (Hofgaard et al. 2016). The inoculum potential (IP) was calculated using the equation below:

$$
\mathrm{IP}=\frac{i b}{t b} \times 100
$$

$i b$ was the number of infected Tenebrio bait, and $t b$ was the total number of Tenebrio baits.

\section{Entomopathogen isolation}

The dead Tenebrio baits were subsequently isolated and purified by using the methods of Herlinda (2010).
Entomopathogenic fungi infecting and growing on integument of Tenebrio bait were isolated and grown on medium of Sabouraud Dextrose Agar (SDA, Merck). The integument surface of larvae infected by the entomopathogenic fungi was previously sterilized using the modified method of Nuraini et al. (2017) with $1 \%$ natrium hypochlorite for 3 minutes and subsequently was rinsed three times with sterile aquadest and air dried on sterile filter paper. The larvae were put into a Petri dish containing sterile humid tissue paper and then incubated in order to stimulate the growth of entomopathogenic fungi. Conidia of entomopathogenic fungi emerging from the dead larvae body were taken by using sterile ose needle and moved into a Petri dish containing SDA medium, and incubated for seven days at the constant temperature of $25{ }^{\circ} \mathrm{C}$ within the incubator.

\section{Identification of Entomopathogen Fungi}

The purified fungi were identified according to macroscopic and microscopic characteristics using the method of Guilherme et al. (2015). Fungi growing on SDA medium with the area of $1 \mathrm{~cm}^{2}$ were taken by using ose needle and put into preparations containing SDA medium, incubated for three days and then microscopically observed. Furthermore, fungi were identified by using books of Humber (2005) and El-Ghany (2015).

\section{Data analysis}

Data on inoculum potentials based on percentage of Tenebrio bait which was infected by the entomopathogenic fungi among the treatments were analyzed descriptively.

\section{RESULTS AND DISCUSSION}

\section{Insect characteristics infected by entomopathogenic fungi}

The fungi obtained in this study were identified as $B$. bassiana and $M$. anisopliae. There were only 30 isolates found from these two fungal species (Table 2). These 30 isolates were isolated from 223 infected larvae of Tenebrio 
bait by the entomopathogenic fungi (Table 3-7); however a lot of larvae were failed to be isolated due to contamination mostly by aerial fungi and Trichoderma spp. These 30 isolates consisted of nine isolates of $B$. bassiana and 21 isolates of $M$. anisopliae.

Tenebrio bait infected by the entomopathogenic fungi showed macroscopic and microscopic characteristics or symptoms that could be used to confirm the determination of the entomopathogenic fungal species. Sick or dead Tenebrio bait infected by B. bassiana showed symptoms as follows: insect body was dry and wrinkle, its outer integument was coated by white mycelia similar to silk, rigid, easily broken and no smell (Figure 2). The Tenebrio bait attacked by $M$. anisopliae showed symptoms as follows: dry and wrinkle, no smell, brittle and easily broken, but its outer integument was coated by mycelia having greenish white to dark green or dark color (Figure 3).

The pure isolate was obtained from dead Tenebrio bait body which was attacked by entomopathogenic fungi with colony characteristics for each species as follows; colony of $B$. bassiana had the white color similar to cotton, but gradually its color changed into yellowish white as fungi become older. Colony of $M$. anisopliae initially had white color similar to color of $B$. bassiana, but the color changed into greenish and dark green or dark as fungi become older (Figure 4). Conidia of B. bassiana and M. anisopliae with specific characteristics were obtained from each colony species of entomopathogenic fungi. Conidia of $B$. bassiana has a single cell and a round shape, whereas conidia of $M$. anisopliae also has a single cell but with a cylindrical shape (Figure 5). Mycelia of B. bassiana and M. anisopliae insulate with upright, branches, and layers of conidiophores.

\section{Inoculum potentials of entomopathogenic fungi in the soil of South Sumatra}

Inoculum potentials of entomopathogenic fungi in this research were measured according to the percentage of infected Tenebrio bait. The inoculum potentials of entomopathogens fungi derived from the freshwater swamp soil, tidal lowlands, peat soils, and high land each was different among the survey locations (Tables 3-6). The value of inoculum potential in soil of freshwater swamps, tidal lowlands, peatlands and high lands were in the range of $0.67-3.33 \%, 2.67-7.33 \%, 0-4 \%$, and $1.33-9.33 \%$, respectively.

From the freshwater swamp soils, we only could obtain five isolates of the entomopathogenic fungi isolated from 35 infected tenebrio baits (Table 3). A lot of the infected Tenebrio baits were failed to be isolated due to the contamination by other fungi. The inoculum potentials of the entomopathogenic fungi from the tidal lowlands gained were only 10 isolates (Table 4). The peat soils in sepucuk, Ogan Komering Ilir were planted with rubber had higher inoculum potentials (Table 5). The highland soils in Talang Patai, Pagaralam were planted with mustard also had higher inoculum potential (Table 6). The highest percentage of inoculum potentials of the fungi was found in the highland ecosystem and the lowest one was found in the freshwater swamp ecosystem. However, the highest number of isolates was found in highland ecosystem (11 isolates) and the lowest one found in peatland ecosystem (4 isolates) (Table 7).

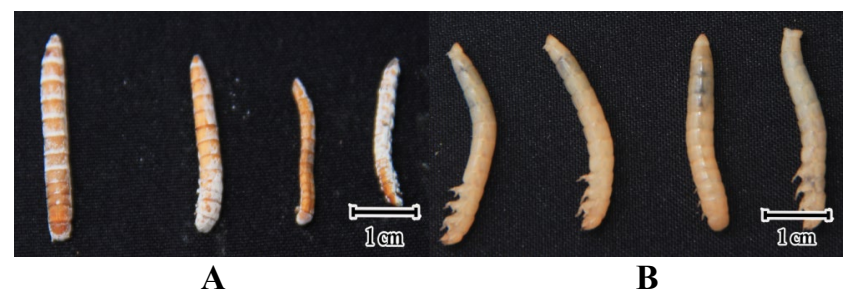

Figure 2. Tenebrio bait infected by Beauveria bassiana (A) and healthy Tenebrio (B)

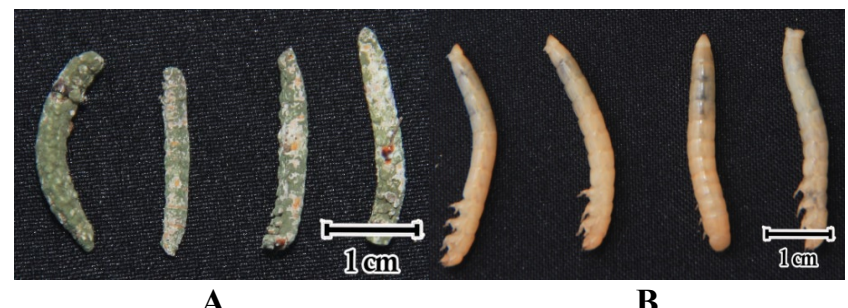

Figure 3. Tenebrio bait infected by Metarhizium anisopliae (A) and healthy Tenebrio (B)

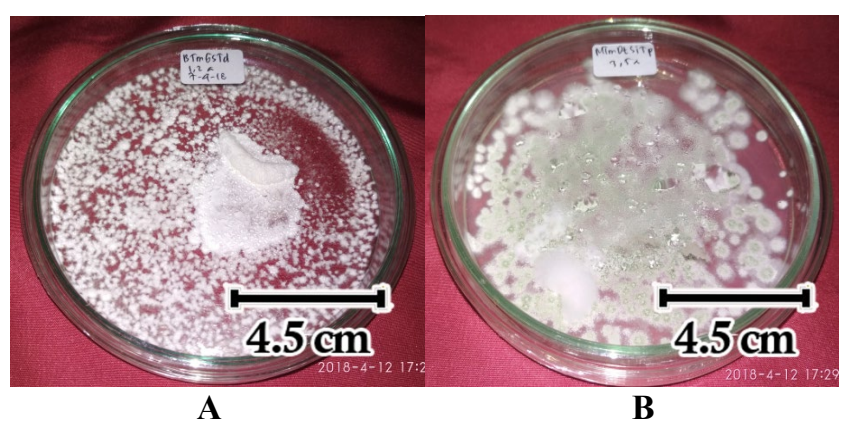

Figure 4. Colony of Beauveria bassiana (A) and Metarhizium anisopliae (B)

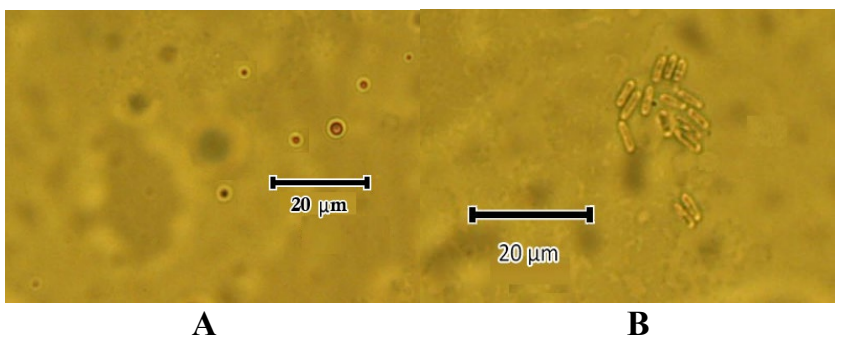

Figure 5. Conidia of Beauveria bassiana (A) and Metarhizium anisopliae (B) (400x magnification) 
Table 2. Species and isolates of entomopathogenic fungi found in South Sumatra, Indonesia

\begin{tabular}{|c|c|c|c|c|}
\hline Ecosystems & Species of fungi & Number of isolate & Vegetation or crop plants & Village or city \\
\hline Freshwater swamps & M. anisopliae & 3 & Paddy & Rambutan \\
\hline Freshwater swamps & M. anisopliae & 1 & Paddy & Pemulutan \\
\hline Freshwater swamps & B. bassiana & 1 & Paddy & Rambutan \\
\hline Tidal lowlands & M. anisopliae & 1 & Corn + coconut & Telang Sari \\
\hline Tidal lowlands & M. anisopliae & 2 & Corn & Telang Sari \\
\hline Tidal lowlands & M. anisopliae & 2 & Corn & Mulya Sari \\
\hline Tidal lowlands & M. anisopliae & 3 & Paddy & Mulya Sari \\
\hline Tidal lowlands & B. bassiana & 1 & Corn & Telang Sari \\
\hline Tidal lowlands & B bassiana & 1 & Watermelon & Mulya Sari \\
\hline Peatlands & B bassiana & 4 & Oil palm & Talang Dabok \\
\hline Highlands & M. anisopliae & 1 & Rubber + coffee & Pulau Pinang \\
\hline Highlands & M. anisopliae & 4 & Cabbage & Talang Patai \\
\hline Highlands & $M$ anisopliae & 4 & Mustard & Talang Patai \\
\hline Highlands & B. bassiana & 1 & Rubber + coffee & Pulau Pinang \\
\hline Highlands & B. bassiana & 1 & Cabbage & Talang Patai \\
\hline
\end{tabular}

Table 3. Inoculum potentials of entomopathogenic fungi in the freshwater swamp soils of South Sumatra, Indonesia

\begin{tabular}{|c|c|c|c|c|c|c|}
\hline \multirow[b]{2}{*}{ Village or city } & \multirow{2}{*}{$\begin{array}{c}\text { Vegetation } \\
\text { or crop } \\
\text { species } \\
\end{array}$} & \multirow[b]{2}{*}{ GPS (coordinat) } & \multicolumn{4}{|c|}{ Inoculum potentials (\%) } \\
\hline & & & $\begin{array}{c}\text { Number of } \\
\text { isolate }\end{array}$ & B. bassiana & M. anisoplia & $\begin{array}{l}\text { Fungi } \\
\text { (total) }\end{array}$ \\
\hline Rambutan, Banyuasin & Paddy & $\mathrm{S} 03^{\circ} 02.581^{\prime}, \mathrm{E} 104^{\circ} 51.231^{\prime}$ & 0 & $0.00(0)$ & $0.67(1)$ & $0.67(1)$ \\
\hline Rambutan, Banyuasin & Paddy & $\mathrm{S} 03^{\circ} 02.591^{\prime}$, E $104^{\circ} 51.217^{\prime}$ & 2 & $0.67(1)$ & $2.00(3)$ & $2.67(4)$ \\
\hline Rambutan, Banyuasin & Paddy & $\mathrm{S} 03^{\circ} 02.586^{\prime}, \mathrm{E} 104^{\circ} 51.201^{\prime}$ & 2 & $0.67(1)$ & $0.67(1)$ & $1.33(2)$ \\
\hline Gandus,Palembang & Paddy & $\mathrm{S} 03^{\circ} 00.401^{\prime}$, E $104^{\circ} 42.380^{\prime}$ & 0 & $1.33(2)$ & $2.00(3)$ & $3.33(5)$ \\
\hline Gandus, Palembang & Paddy & $\mathrm{S} 03^{\circ} 00.632^{\prime}$, E $104^{\circ} 42.532^{\prime}$ & 0 & $0.67(1)$ & $0.67(1)$ & $1.33(2)$ \\
\hline Gandus,Palembang & Paddy & $\mathrm{S} 03^{\circ} 00.632^{\prime}$, E $104^{\circ} 42.801^{\prime}$ & 0 & $1.33(2)$ & $1.33(2)$ & $2.67(4)$ \\
\hline Musi Dua, Palembang & Paddy & $\mathrm{S} 03^{\circ} 02.120^{\prime}, \mathrm{E} 104^{\circ} 43.021^{\prime}$ & 0 & $0.67(1)$ & $1.33(2)$ & $2.00(3)$ \\
\hline MusiDua, Palembang & Paddy & $\mathrm{S} 03^{\circ} 02.150^{\prime}$, E $104^{\circ} 43.612^{\prime}$ & 0 & $1.33(2)$ & $2.00(3)$ & $3.33(5)$ \\
\hline Musi Dua, Palembang & Paddy & $\mathrm{S} 03^{\circ} 02.510^{\prime}$, E $104^{\circ} 43.120^{\prime}$ & 0 & $1.33(2)$ & $1.33(2)$ & $2.67(4)$ \\
\hline Pemulutan, Ogan Ilir & Paddy & $\mathrm{S} 03^{\circ} 03.148^{\prime}$, E $104^{\circ} 46.230^{\prime}$ & 0 & $0.67(1)$ & $0.67(1)$ & $1.33(2)$ \\
\hline Pemulutan, Ogan Ilir & Paddy & $\mathrm{S} 03^{\circ} 03.115^{\prime}$, E $104^{\circ} 46.218^{\prime}$ & 0 & $0.67(1)$ & $0.67(1)$ & $1.33(2)$ \\
\hline Pemulutan, Ogan Ilir & Paddy & $\mathrm{S} 03^{\circ} 03.113^{\prime}$, E $104^{\circ} 46.201^{\prime}$ & 1 & $1.33(2)$ & $1.33(2)$ & $2.67(4)$ \\
\hline
\end{tabular}

Table 4. Inoculum potentials of entomopathogenic fungi in the tidal lowland soils of South Sumatra, Indonesia

\begin{tabular}{|c|c|c|c|c|c|c|}
\hline \multirow[b]{2}{*}{ Village or city } & \multirow[b]{2}{*}{$\begin{array}{l}\text { Vegetation or } \\
\text { crop species }\end{array}$} & \multirow[b]{2}{*}{ GPS (coordinat) } & \multicolumn{4}{|c|}{ Inoculum potentials (\%) } \\
\hline & & & $\begin{array}{c}\text { Number of } \\
\text { isolate }\end{array}$ & B. bassiana & M. anisoplia & $\begin{array}{l}\text { Fungi } \\
\text { (total) }\end{array}$ \\
\hline Mulya Sari, Banyuasin & Corn & S $02^{\circ} 40.866^{\prime}$, E $104^{\circ} 44.298^{\prime}$ & 2 & $1.33(2)$ & $2.67(4)$ & $4.00(6)$ \\
\hline Mulya Sari, Banyuasin & Paddy & S $02^{\circ} 40.944^{\prime}$, E $104^{\circ} 44.621$ & 3 & $1.33(2)$ & $2.00(3)$ & $3.33(5)$ \\
\hline Mulya Sari, Banyuasin & Watermelon & S $02^{\circ} 40.896^{\prime}$, E $104^{\circ} 44.676^{\prime}$ & 1 & $1.33(2)$ & $2.00(3)$ & $3.33(5)$ \\
\hline Telang Sari, Banyuasin & Corn & S $02^{\circ} 38.842^{\prime}$, E $104^{\circ} 45.369^{\prime}$ & 2 & $1.33(2)$ & $2.67(4)$ & $4.00(6)$ \\
\hline Telang Sari, Banyuasin & Coconut & $\mathrm{S} 02^{\circ} 38.813^{\prime}, \mathrm{E} 104^{\circ} 45.801^{\prime}$ & 1 & $0.67(1)$ & $1.33(2)$ & $2.00(3)$ \\
\hline Telang Sari, Banyuasin & Corn + coconut & $\mathrm{S} 02^{\circ} 38.875^{\prime}, \mathrm{E} 104^{\circ} 44.495^{\prime}$ & 1 & $2.00(3)$ & $5.33(8)$ & $7.33(11)$ \\
\hline Muara Sungsang, Banyuasin & Coconut & $\mathrm{S} 02^{\circ} 21.736^{\prime}, \mathrm{E} 104^{\circ} 50.635^{\prime}$ & 0 & $1.33(2)$ & $4.00(6)$ & $5.33(8)$ \\
\hline Muara Sungsang, Banyuasin & Banana & S $02^{\circ} 21.823^{\prime}$, E $104^{\circ} 50.632^{\prime}$ & 0 & $0.67(1)$ & $2.00(3)$ & $2.67(4)$ \\
\hline Muara Sungsang & Pineapple & $\mathrm{S} 02^{\circ} 22.542^{\prime}, \mathrm{E} 104^{\circ} 50.324^{\prime}$ & 0 & $0.67(1)$ & $2.00(3)$ & $2.67(4)$ \\
\hline
\end{tabular}


Table 5. Inoculum potentials of entomopathogenic fungi in the peatland soils of South Sumatra, Indonesia

\begin{tabular}{|c|c|c|c|c|c|c|}
\hline \multirow{2}{*}{ Village or city } & \multirow{2}{*}{$\begin{array}{c}\text { Vegetation } \\
\text { or crop } \\
\text { plants }\end{array}$} & \multirow[b]{2}{*}{ GPS (coordinat) } & \multicolumn{4}{|c|}{ Inoculum potentials (\%) } \\
\hline & & & $\begin{array}{c}\text { Number of } \\
\text { isolate }\end{array}$ & B. bassiana & $\begin{array}{c}\text { M. } \\
\text { anisoplia }\end{array}$ & $\begin{array}{l}\text { Fungi } \\
\text { (Total) }\end{array}$ \\
\hline Talang Dabok, & Oil palm & 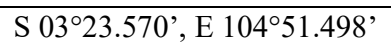 & 4 & $3.33(5)$ & $1.33(2)$ & $4.67(7)$ \\
\hline Talang Dabok, Oga1 & Rubber & S $03^{\circ} 25.673^{\prime}$, E $104^{\circ} 53.258^{\prime}$ & 0 & $2.67(4)$ & $1.33(2)$ & $4.00(6)$ \\
\hline Talang Dabok, Ogan Komering Ilir & Pineapple & $\mathrm{S} 03^{\circ} 25.280^{\prime}$, E $104^{\circ} 52.940^{\prime}$ & 0 & $2.00(3)$ & $0.67(1)$ & $2.67(4)$ \\
\hline Sepucuk, Ogan Komering Ilir & Oil palm & $\mathrm{S} 03^{\circ} 24.840^{\prime}$, E $104^{\circ} 53.362^{\prime}$ & 0 & $2.00(3)$ & $1.33(2)$ & $3.33(5)$ \\
\hline Sepucuk, Ogan Komering Ilir & Rubber & $\mathrm{S} 03^{\circ} 23.715^{\prime}$, E $104^{\circ} 52.275^{\prime}$ & 0 & $3.33(5)$ & $2.00(3)$ & $5.33(8)$ \\
\hline Sepucuk, Ogan Komering Ilir & Pineapple & $\mathrm{S} 03^{\circ} 23.535^{\prime}, \mathrm{E} 104^{\circ} 51.780^{\prime}$ & 0 & $1.33(2)$ & $1.33(2)$ & $2.67(4)$ \\
\hline Kedaton, Ogan Komering Ilir & Oil p & $\mathrm{S} 03^{\circ} 23.308^{\prime}$, E $104^{\circ} 51.4$ & 0 & $1.33(2)$ & $2.00(3)$ & $3.33(5)$ \\
\hline Kedaton, Ogan Komering Ilir & Oil palm & S $03^{\circ} 23.277^{\prime}$, E $104^{\circ} 51.398^{\prime}$ & 0 & $1.33(2)$ & $0.67(1)$ & $2.00(3)$ \\
\hline Kedaton, Ogan Komering Ilir & Oil palm & $\mathrm{S} 03^{\circ} 23.204^{\prime}, \mathrm{E} 104^{\circ} 51.459^{\prime}$ & 0 & $1.33(2)$ & $0.67(1)$ & $2.00(3)$ \\
\hline
\end{tabular}

Table 6. Inoculum potentials of entomopathogenic fungi in the highland soils of South Sumatra, Indonesia

\begin{tabular}{|c|c|c|c|c|c|c|}
\hline \multirow[b]{2}{*}{ Village or city } & \multirow{2}{*}{$\begin{array}{c}\text { Vegetation or crop } \\
\text { plants }\end{array}$} & \multirow[b]{2}{*}{ GPS (coordinat) } & \multicolumn{4}{|c|}{ Inoculum potentials (\%) } \\
\hline & & & $\begin{array}{c}\begin{array}{c}\text { Number of } \\
\text { isolate }\end{array} \\
\end{array}$ & $\begin{array}{c}\text { B. } \\
\text { bassiana }\end{array}$ & M. anisoplia & $\begin{array}{l}\text { Fungi } \\
\text { (total) }\end{array}$ \\
\hline Pulau Pinang, Lahat & Rubber + coffee $(\mathrm{A})$ & 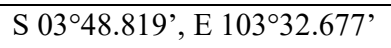 & 2 & $1.33(2)$ & $1.33(2)$ & $2.67(4)$ \\
\hline Pulau Pinang, Lahat & Rubber + coffee $(B)$ & S $03^{\circ} 48.852^{\prime}$, E $103^{\circ} 32.698^{\prime}$ & 0 & $1.33(2)$ & $2.00(3)$ & $3.33(5)$ \\
\hline Pulau Pinang, Lahat & Rubber + coffee $(C)$ & $\mathrm{S} 03^{\circ} 48.883^{\prime}$, E $103^{\circ} 32.688^{\prime}$ & 0 & $0.67(1)$ & $0.67(1)$ & $1.33(2)$ \\
\hline Tanjung Payang, Lahat & Rubber (A) & S $03^{\circ} 48.094^{\prime}$, E $103^{\circ} 32.145^{\prime}$ & 0 & $0.67(1)$ & $1.33(2)$ & $2.00(3)$ \\
\hline Tanjung Payang, Lahat & Rubber (B) & S $03^{\circ} 48.122^{\prime}$, E $103^{\circ} 32.162^{\prime}$ & 0 & $3.33(5)$ & $2.67(4)$ & $6.00(9)$ \\
\hline Tanjung Payang, Lahat & Rubber (C) & S $03^{\circ} 48.177^{\prime}$, E $103^{\circ} 32.166^{\prime}$ & 0 & $2.00(3)$ & $2.67(4)$ & $4.67(7)$ \\
\hline Lematang, Lahat & Paddy & S $03^{\circ} 48.063^{\prime}$, E $103^{\circ} 32.072^{\prime}$ & 0 & $0.67(1)$ & $1.33(2)$ & $2.00(3)$ \\
\hline Lematang, Lahat & Paddy & S $03^{\circ} 48.051^{\prime}$, E $103^{\circ} 32.069^{\prime}$ & 0 & $3.33(5)$ & $4.00(6)$ & $7.33(11)$ \\
\hline Lematang, Lahat & Paddy & S $03^{\circ} 48.020^{\prime}$, E $103^{\circ} 32.064^{\prime}$ & 0 & $1.33(2)$ & $1.33(2)$ & $2.67(4)$ \\
\hline Talang Patai, Pagaralam & Cabbage & S $03^{\circ} 50.180^{\prime}$, E $103^{\circ} 31.325^{\prime}$ & 2 & $4.00(6)$ & $4.67(7)$ & $8.67(13)$ \\
\hline Talang Patai, Pagaralam & Cabbage & S $03^{\circ} 50.174^{\prime}$, E $103^{\circ} 31.313^{\prime}$ & 3 & $0.67(1)$ & $1.33(2)$ & $2.00(3)$ \\
\hline Talang Patai, Pagaralam & Mustard & S $03^{\circ} 50.174^{\prime}$, E $103^{\circ} 31.293^{\prime}$ & 4 & $4.67(7)$ & $4.67(7)$ & $9.33(14)$ \\
\hline Rimau, Pagaralam & Tea & S $04^{\circ} 02.161^{\prime}$, E $103^{\circ} 10.484^{\prime}$ & 0 & $2.00(3)$ & $2.00(3)$ & $4.00(6)$ \\
\hline Rimau, Pagaralam & Tea & S $04^{\circ} 02.144^{\prime}$, E $103^{\circ} 10.487^{\prime}$ & 0 & $1.33(2)$ & $1.33(2)$ & $2.67(4)$ \\
\hline Rimau, Pagaralam & Tea & $\mathrm{S} 04^{\circ} 02.136^{\prime}, \mathrm{E} 103^{\circ} 10.485^{\prime}$ & 0 & $0.67(1)$ & $1.33(2)$ & $2.00(4)$ \\
\hline
\end{tabular}

Table 7. Inoculum potentials of entomopathogenic fungi in the soil of South Sumatra, Indonesia

\begin{tabular}{lcccc}
\hline \multirow{2}{*}{ Ecosystems } & \multicolumn{4}{c}{ Inoculum potentials (\%) } \\
\cline { 2 - 5 } & Number of isolate & B. bassiana & M. anisoplia & Fungi (total) \\
\hline Freshwater Swamps & 5 & $0.89(16)$ & $1.22(22)$ & $2.11(38)$ \\
Tidal Lowlands & 10 & $1.18(16)$ & $2.67(36)$ & $3.85(52)$ \\
Peatlands & 4 & $2.07(28)$ & $1.25(17)$ & $3.33(45)$ \\
Highlands & 11 & $1.87(42)$ & $2.17(49)$ & $4.04(91)$ \\
\hline
\end{tabular}

\section{Discussion}

Entomopathogenic species found in this research were B. bassiana and M. anisopliae. Macroscopic and microscopic characteristics of both entomopathogenic fungi found in this research matched with the previous studies. Humber (2005) stated that mycelia of B. bassiana appeared from exoskeleton of hosts insect, and covered all parts of the exterior surface of host integument, so that host body has white color, reverse pale to yellow colony, hyaline or colorless, single cell, and globular and conidia as well as insulate hypha. M. anisopliae causes integument which has colors of whitish green to dark green because its mycelia cover exoskeleton of hosts insect; it has green to yellow conidia, single cell and cylindrical conidia as well as insulate hypha (Driver et al. 2000; Humber 2005).

Beauveria bassiana and M. anisopliae have parasitic and saprophytic phases during the killing process of their host insect (Augustyniuk-Kram and Kram 2012; El-Ghany 2015). Parasitic phase starts viz, the fungal conidia attach to the host insect cuticle, and then the conidia germinate on the host cuticle (El-Ghany 2015). The fungal penetration into the insect cuticle can be performed in producing 
specific infection hyphae originating at appressoria of the fungus (Fernandes et al. 2007; El-Ghany 2015). Gürlek et al. (2018) reported that both species could produce germ tubes growing over the surface of the insect cuticle until the tubes contacted weakness area of cuticle where penetration could easily be achieved. After the fungus successfully penetrated, then mycelia distributed into the hemolymph by the formation of blastospores (El-Ghany 2015). Finally, the host insect would die within four days of penetration (Gürlek et al. 2018). Saprophytic phase starts viz, the fungus grew mechanically in the dead insect body, retrieved nutrients from the insect body, and then the fungus produced toxins (El-Ghany 2015).

The success of both fungi in conducting the process of parasitic and saprophytic phases was affected by several external factors such as moisture, $\mathrm{pH}$, temperature, ultraviolet (UV) radiation, and vegetation (El-Ghany 2015). This research showed that highland soil planted with cabbage and mustard in Talang Patai, Pagaralam had more inoculum potentials of entomopathogenic fungi than other locations because cabbage and mustard were inhabited by insect pests dominated by Lepidoptera, such as Plutella xylostella, Crocidolomia binotalis, Spodoptera litura, and Chrysodeixis chalcites; while the larvae of Lepidoptera were the most suitable hosts for entomopathogenic fungi (Godonou et al. 2009; Nunilahwati et al. 2012). This study also found that a lot of infected larvae of the insect pests hung above of the mustard and cabbage canopy. The host insects attacked by entomopathogenic fungi on the cabbage canopy at highlands, South Sumatra were generally dominated by P. xylostella, S. litura, and C. chalcites. The symptoms of sick or infected insect larvae were dry and in the stiff condition, white or greenish white in color and attached on the upper surface of cabbage leaves. The infected larvae which showed the symptoms of dry and stiff condition as mummy and covered with white fungal mycelia was larvae attacked by $B$. bassiana, whereas larvae body covered by fungal mycelia having greenish white or dark green color was symptoms of larvae attacked by $M$. anisopliae. Symptoms of larvae attacked by $B$. bassiana and $M$. anisopliae in this research matched to the symptoms reported by El-Ghany (2015) and Mora et al. (2017).

In this research, more inoculum potentials of the entomopathogenic fungi were found in the highlands and tidal lowlands than that in freshwater swamps and peatlands because it was affected by soil $\mathrm{pH}$ and moisture. Zhong et al. (2010) reported that soil $\mathrm{pH}$ had a more significant role in determining the existence of fungal propagules within soils than that of soil texture and organic matter. However, Inubushi et al. (2003) had stated that soil moisture is one of the most important controlling factors for biological reactions in the soil. Soil $\mathrm{pH}$ in this research was in the range of 4 to 4.5 in freshwater swamps, 4.3 to 5 in tidal lowlands, 3.60 to 4 in peatlands, and 5 to 6.7 in highlands. Kodir and Juwita (2016) stated that the $\mathrm{pH}$ value of soil in freshwater swamps in Indonesia are in the ranges of 4 to $4.5, \mathrm{pH} 4.17$ to 5.35 in tidal lowlands (Marlina et al. 2016), and 3.60 to 3.95 in peatlands (Utami et al. 2009), and 5 to 6 in highlands (Supriadi et al. 2016). The variation of
$\mathrm{pH}$ values of soils at each location could affect the adaptation capability of entomopathogenic fungi surviving (Bugeme et al. 2008). The conidial viability of entomopathogenic fungi, such as $B$. bassiana and $M$. anisopliae were affected by $\mathrm{pH}$ of in-vitro medium for entomopathogenic fungi. Rizkie et al. (2017) reported that high acidity $(\mathrm{pH}<4)$ of in-vitro medium for fungus growing significantly decrease the conidial viability of $B$. bassiana and M. anisopliae. Therefore, inoculum potentials of the entomopathogenic fungi from peatland soil and freshwater swamp soil were lower than that from the soil in the tidal lowlands and highlands.

In addition to soil $\mathrm{pH}$ and moisture, soil texture also determines the existence and distribution of fungal propagules. Soil texture has low clay content, and sandy soil texture tends to have the low capability in maintaining the existence of fungal propagules (El-Ghany 2015) as well as the water saturated soil (Garrido-Jurado et al. 2011). Soils from freshwater swamps and peatlands in South Sumatra had lower clay content and in water saturated condition (Marlina et al. 2016; Kartika et al. 2018). The low existence of fungal propagules finding at freshwater swamp and peatland soils was due to both factors. Soils in freshwater swamps are water saturated for more than 6 to 7 months per year usually occurred from November to April (Herlinda et al. 2018) and soil moisture in the peatlands reach 500\% (Maftu'ah and Susanti 2009).

Peatlands have soil pore saturated with water all year long resulting in the anaerobic condition of the soil. Peat soil has no clay, sand, and silt content, but it has organic matter (Sudana 2005). The high organic matter finally can decrease the $\mathrm{pH}$ of the soil (Utami et al. 2009). Rizkie et al. (2017) confirmed that $\mathrm{pH}<4$ within medium in-vitro for growing fungi could decrease the ability to live of fungal propagules. In highland ecosystems, the portion of the soil texture among clay, sand, and silt fractions was found in the same composition or balance (Utomo et al. 2013; Supriadi et al. 2016). While tidal lowlands contain silt from sedimentation mixture of river water and seawater with balance clay and sand fractions (Marlina et al. 2016). Higher inoculum potentials in highlands and tidal lowlands in this research was due to balance or higher of clay texture and organic soils than that of freshwater swamps and peatlands.

The balance or higher of clay texture and organic soils are capable of maintaining the existence of fungal propagules (Garrido-Jurado et al. 2011). Zhong et al. (2010) stated that soil in ecosystems which apply composted manure or no synthetic fertilizer had higher propagules content of $B$. bassiana than that of soil in the ecosystem which applies synthetic fertilizers. Also, the application of synthetic pesticides is capable of decreasing the existence of entomopathogenic fungi within the soil (Mietkiewski et al. 2010). Local farmers in freshwater swamp and peatland areas of South Sumatra usually do not apply synthetic pesticides, whereas many local farmers in tidal lowland and highland areas apply synthetic pesticides (Herlinda et al. 2018). Although no synthetic pesticides were applied in the freshwater swamp and peatland areas, fungal propagules or inoculum potentials in these areas were lower than those of tidal lowlands and highlands 
areas. In this study, there was no evidence that having no synthetic pesticide application in freshwater swamp and peatland areas can cause the high existence of fungal propagules. However, soil $\mathrm{pH}$ and soil texture have more effect on the existence of propagules of B. bassiana and $M$. anisopliae in lowland swamp and peatland ecosystems.

Higher inoculum potentials in highlands and tidal lowlands in this research were closely related to specific cultivated vegetations or crops. Most peatlands in Indonesia were utilized for forestry and conservation areas (Suriadikarta and Sutriadi 2007). Paddy generally is cultivated at freshwater swamps (Herlinda et al. 2018; Lakitan et al. 2018a; Lakitan et al. 2018b) as well as in tidal lowlands; however, paddy cultivation at tidal lowlands was more intensive (with two to three planting indices) than that of freshwater swamps (one planting index). Thus, diverse species of vegetation or crop plants could affect abundant and diverse species of the soil microorganisms associated with plant and crop roots (El-Ghany 2015).

This research found two species of entomopathogenic fungi from soils in South Sumatra i.e., B. bassiana and $M$. anisopliae. The highest percentage of the inoculum potentials and prevalence of both fungi occurred in the highland ecosystems and the lowest percentage of the inoculum potentials of the fungi was found in the peatland ecosystems. In highland ecosystems, the percentage of the inoculum potentials was affected by the locations and the vegetation or the crop plants. These fungi will make an important contribution to the biological control for insect pests from lowland to highland ecosystems in Indonesia.

\section{ACKNOWLEDGEMENTS}

This research was funded by National Strategic Research (PSNI)with budget year of 2018 according to the Director of Research and Community Service, Directorate of Research and Community Service (DRPM), Directorate General for Research and Development, Ministry of Research, Technology, and Higher Education, Number: 093/SP2H/LT/DRPM/IV/2018 chaired by Siti Herlinda. Special thanks to Dr. Suwandi, a microbiologist from Universitas Sriwijaya, Palembang, Indonesia for identification of fungi.

\section{REFERENCES}

Anwar W, Khan SN, Aslam M, Haider MS, Shahid AA, Ali M. 2015 Exploring fungal flora associated with insects of cotton agroecological zones of Punjab, Pakistan. Pakistan Entomologist 37: 27-31.

Augustyniuk-Kram A, Kram KJ. 2012. Entomopathogenic fungi as an important natural regulator of insect outbreaks in forests review. Forest Ecosystem, More than Just Trees. Blanco JA. (ed.). In Tech: Croatia

Bugeme DM, Maniania NK, Knapp M, Boga HI. 2008. Effect of temperature on virulence of Beauveria bassiana and Metarhizium anisopliae isolates to Tetranychus evansi. Exp Appl Acarol 46: 275285.

Center for Agriculture Data and Information System, Secretariat General. 2017. Statistics of Agricultural Land 2012-2016. In. Hakim M,
Wiratno $\mathrm{O}$, and Abdurachman A (eds). Ministry of Agriculture. Jakarta.

Chen Z, Xu L, Yang F, Ji G, Yang J, Wang J. 2014. Efficacy of Metarhizium anisopliae isolate MAX-2 from Shangri-la, China under desiccation stress. BMC Microbiol 14: 1-8.

Driver F, Milner RJ, Trueman JWH. 2000. A taxonomic revision of Metarhizium based on a phylogenetic analysis of rDNA sequence data. Mycol Res104: 134-150.

El-Ghany TMA. 2015. Entomopathogenic Fungi and their Role in Biological Control. Biology Department Faculty of Science Jazan University KSA. Cairo.

Erler F, Ates AO. 2015. Potential of two entomopathogenic fungi, Beauveria bassiana and Metarhizium anisopliae (Coleoptera: Scarabaeidae), as biological control agents against the June beetle. J Insect Sci 15: 1-6.

Fernandes EKK, Rangel DEN, Moraes AM., Bittencourt VREP, Roberts DW. 2007. Variability in tolerance to UV-B radiation among Beauveria spp. isolates. J Invertebr Pathol 96: 237-243.

Garrido-Jurado J, Torrent J, Barrón V, Corpas A, Quesada-Moraga E. 2011. Soil properties affect the availability, movement, and virulence of entomopathogenic fungi conidia against puparia of Ceratitis capitata (Diptera: Tephritidae). Biol Control 58: 277-285.

Godonou I, James B, Atcha-Ahowé B, Vodouhe S, Kooyman C, Ahanchédé A, Korie S. 2009. Potential of Beauveria bassiana and Metarhizium anisopliae isolates from Benin to control Plutella xylostella L. (Lepidoptera: Plutellidae). Crop Protection 28: 220-224.

Guilherme D, Oliveira P, Pauli G, Moura G, Delalibera I. 2015. A protocol for determination of conidial viability of the fungal entomopathogens Beauveria bassiana and Metarhizium anisopliae from commercial products. J Microbiol Methods 119: 44-52.

Gürlek S, Sevim A, Sezgin FM, Sevim E. 2018. Isolation and characterization of Beauveria and Metarhizium spp. from walnut fields and their pathogenicity against the codling moth, Cydia pomonella (L.) (Lepidoptera: Tortricidae). Egyptian J Biol Pest Control 28: 1-6.

Hasyim A, Nuraida, Trizelia. 2009. Pathogenicity of entomopathogenic fungi isolates to eggs and larvae of cabbage head caterpillar, Crocidolomia pavonana Fabricius. J Hort 19: 334-343.

Herlinda S. 2010. Spore density and viability of entomopathogenic fungal isolates from Indonesia, and their virulence against Aphis gossypii Glover (Homoptera: Aphididae). Tropical Life Sci Res 21: 11-19.

Herlinda S, Irsan C, Mayasari R, Septariani S. 2010. Identification and selection of entomopathogenic fungi as biocontrol agents for Aphis gossypii from South Sumatra. Microbiol Indonesia 4: 137-142.

Herlinda S, Mulyati SI, Suwandi. 2008. Selection of isolates of entomopathogenic fungi and the bioefficacy of their liquid production against Leptocorisa oratorius nymphs. Microbiol Indonesia 2: 141146.

Herlinda S, Yudha S, Thalib R, Khodijah, Suwandi, Lakitan B, Verawaty M. 2018. Species richness and abundance of spiders inhabiting rice in freshwater swamps and tidal lowlands in South Sumatra, Indonesia. J ISSAAS 24: 82-93.

Hofgaard IS, Seehusen T, Aamot HU, Riley H, Razzaghian J, Le VH, Hjelkrem A-GR, Dill-Macky R, Brodal G. 2016. Inoculum potential of Fusarium spp. relates to tillage and straw management in Norwegian fields of spring oats. Front Microbiol 7: 1-15.

Humber RA. 2005. Entomopathogenic Fungal Identification. USDA-ARS Plant Protection Research Unit. Ithaca.

Inubushi K, Furukawa Y, Hadi A, Purnomo E, Tsuruta H. 2003. Seasonal changes of $\mathrm{CO}_{2}, \mathrm{CH}_{4}$ and $\mathrm{N}_{2} \mathrm{O}$ fluxes in relation to land-use change in tropical peatlands located in coastal area of South Kalimantan. Chemosphere 52: 603-608.

Kartika K, Lakitan B, Wijaya A, Kadir S, Widuri LI, Siaga E. 2018. Effects of particle size and application rate of rice-husk biochar on chemical properties of tropical wetland soil, rice growth and yield. AJCS 12: 817-826.

Kodir KA, Juwita Y. 2016. Morphological characterization and inventory of local wetland rice collected from South Sumatra Province. Bul Plasma Nutfah 22: 101-108.

Lakitan B, Alberto A, Lindiana L, Kartika K, Herlinda S, Kurnianingsih A. 2018. The Benefits of biochar on rice growth and yield in tropical riparian wetland, South Sumatra, Indonesia. CMUJ Natural Sciences 17: $111-126$.

Lakitan B, Hadi B, Herlinda S, Siaga E, Widuri LI, Kartika K, Lindiana L, Yunindyawati Y, Meihana M. 2018. Recognizing farmers practices and constraints for intensifying rice production at riparian wetlands in 
Indonesia. NJAS Wageningen J Life Sci 85: 10-20.

Leland JE, Mcguire MR, Grace JA, Jaronski ST, Ulloa M, Park Y, Plattner RD. 2005. Strain selection of a fungal entomopathogen, Beauveria bassiana, for control of plant bugs (Lygus spp.) (Heteroptera : Miridae). Biol Control 35: 104-114

Loc NT, Chi VTB. 2007. Biocontrol potential of Metarhizium anisopliae and Beauveria bassiana against diamond back moth, Plutella xylostella. Omonrice 93: 86-93.

Maftu'ah E, Susanti MA. 2009. Earthworms community on several land uses of peat land in Central Kalimantan. Berita Biologi 9:371-378

Marlina N, Asmawati, Zairani FY, Midranisiah, Aryani I, Kalasari R. 2016. Biofertilizer utilization in increasing inorganic fertilizer efficiency and rice yield at c-type flooding land of Tanjung Lago tidal lowland. Int J Engg res \& Sci \& Tech 5: 74-83.

Mietkiewski RT, Pell JK, Clark SJ. 2010. Influence of pesticide use on the natural occurrence of entomopathogenic fungi in arable soils in the UK: Field and laboratory comparisons. Biocontrol Science and Technology 7: 565-575.

Mora MAE, Castilho AMC, Fraga ME. 2017. Classification and infection mechanism of entomopathogenic fungi. Arq Inst Biol 84: 1-10.

Moslim R, Kamarudin N, Wahid MB. 2009. Pathogenicity of granule formulations of Metarhizium anisopliae against the larvae of the oil palm rhinoceros beetle, Oryctes rhinoceros. J Oil Palm Res 21: 602612.

Mulyani A, Sarwani M. 2013. The characteristic and potential of suboptimal land for agricultural development in Indonesia. Jurnal Sumberdaya Lokal 7: 47-55. [Indonesian]

Nunilahwati H, Herlinda S, Irsan C, Pujiastuti Y. 2012. Exploration, isolation and selection entomopathogenic fungi infectious to Plutella xylostella (Lepidoptera: Yponomeutidae) on green mustard (Brassica chinensis) crop in South Sumatra. J HPT Tropika 12: 1-11. [Indonesian]

Nuraini FR, Setyaningsih R, Susilowati ARI. 2017. Screening and characterization of endophytic fungi as antagonistic agents toward Fusarium oxysporum on eggplant (Solanum melongena). Biodiversitas 18: 1377-1384.

Rizkie L, Herlinda S, Suwandi, Irsan C, Susilawati, Lakitan B. 2017. Conidial density and viability of Beauveria bassiana and Metarhizium anisopliae grown on the low-pH in vitro medium. J HPT Tropika17: 119-127. [Indonesian]

Sudana W. 2005. The potential and prospect of swamps as a source of agricultural production. Analisis Kebijakan Pertanian 3: 141-151. [Indonesian]

Supriadi H, Randriani E, Towaha J. 2016. Correlation between altitude, soil chemical properties, and physical quality of arabica coffee beans in highland areas of Garut. J TIDP 3: 45-52.

Suriadikarta DA, Sutriadi MT. 2007. Potential tidal land for agricultural development. The Jurnal Litbang Pertanian 26: 115-122. [Indonesian]

Utami SNH, Maas A, Radjagukguk B, Purwanto BH. 2009. Nature on soil phisical, chemical and ftir spectrophotometry of hydrophobic peat from Central Kalimantan. J Trop Soils 14: 159-166.

Utomo M, Banuwa IS, Buchari H, Anggraini Y. 2013. Long-term tillage and nitrogen fertilization effects on soil properties and crop yields. $\mathrm{J}$ Trop Soils 18: 131-139.

Zhong W, Gu T, Wang W. 2010. The effects of mineral fertilizer and organic manure on soil microbial community and diversity. Plant Soil 326: $511-522$ 